\title{
The Antihypertensive Property of Methanolic Extract of New Bouldia Laevis on Anaesthesized Cats
}

\author{
Enye J.C. ${ }^{1}$, Onubeze D.P.M. ${ }^{2}$, Chineke H.N. ${ }^{3}$, Nweke I ${ }^{4}$. \\ ${ }^{I}$ Department of Pharmacology And Toxicology Madonna University Elele Rivers State. \\ ${ }^{2}$ Department of Community Medicine \& Primary care, Anambra State University Teaching Hospital, Awka, \\ Nigeria \\ ${ }^{3}$ Department of Family Medicine Imo State University Teaching Hospital Orlu. \\ ${ }^{4}$ Department of Pharmacology, Abia State University Teaching Hospital, Aba, Nigeria.
}

\begin{abstract}
Background: The plant Newbouldia laevis, commonly known as boundary tree, is a medium sized angiosperm which belongs to the family of Bignoniaceae. It is a native of trospical Africa. Extracts of all parts of Newbouldia laevis have been shown to exhibit antihypertensive property. Blood pressure is the optimal force needed to move blood through the body at rest and during physical activity while not exposing the arterial system to excessive force.

An increase in blood pressure above the optimal level for an individual indicates that the cardiovascular system is abnormal in some way, and if this persists, damage to the heart and other vital organs will occur. Hypertension is not a threshold disease even though the current definition is commonly equated with blood pressure level above ${ }^{140} / 90 \mathrm{mmHg}$.

Objectives: To investigate the antihypertensive property of methanolic extract of Newbouldia Laevis on adult cats. This could be of relevance in the treatment of hypertension in clinical medicine in the near future.

Methodology: An operating table was set up and ten adult cats of either sex were given pentobarbitone injection $(40 \mathrm{mg} / \mathrm{kg}$ ) intraperitoneally. Little quantity of diethylether was given to the animals by inhalation so as to fully anaesthesize the animals. The animals were then made to lie on their back on the operating table with the fore and hind limbs tied firmly to the table. Incisions were made on their neck regions and the left hind limbs and cannulas were fixed on three points; the femoral vein, the carotid artery and the trachea. Heparin was injected through the femoral vein to aid free flow of blood. The carotid artery cannula was connected to a blood pressure transducer which was also linked to an electric recorder which made tracing showing the effect of the drugs on the blood pressure of the animals. The different doses of the extract were administered through the femoral vein until the end of the experiment.
\end{abstract}

Results: The result showed that at the doses of 10-100ug, the extract gave a blood pressure lowering effect. When the control was administered, there was no effect on the blood pressure of the cats, while the standards showed expected effects. The acute toxicity test showed that proteins, alkaloids, oil, acidic compound, resins, carbohydrate, flavinoids, reducing sugar and tannin were present.

Conclusion: The extract of Newbouldia Laevis exhibited anti-hypertensive action. This could find some relevance in the treatment of hypertension in clinical medicine. Clinicians and pharmacologists will find this study highly relevant with a view to actually formulating a medicament from the extract that could be effectively used in humans for the treatment of hypertension.

Key Words: Antihypertensive, Newbouldia laevis cats.

\section{Introduction}

The plant Newbouldia Laevis or boundary tree is locally called Aduruku in Hausa, Ogirisi in Igbo and Akoko in Yoruba languages. It is a medium sized angiosperm which belongs to the Bignoniaceae family. It grows to a height of about 7-8 meters with many stem-forming clumps of gnarled branches. ${ }^{(1)}$

Newbouldia Laevis is a native to tropical Africa and grows from the Guinea Savannahs to the tropical rain forests, on moist and well drained soils. It inhabits the secondary forest extending from Senegal to Cameroon, Garbon, Democratic Republic of Congo, Angola etc Newbouldia laevis. ${ }^{(1)}$

Extracts of all parts of leaves, viz the stem, bark and roots have been shown to exhibit, anti microbial, anti-malaria, anti-oxidant and anti-coagulant activities amongst others ${ }^{(2)(3)}$. Recently it has been shown to possess anti-hypertensive properties

Hypertension is an increase in the blood pressure above the optimal level for an individual. If this pressure increase remains unabated, significant end organ damages will occur ${ }^{(4)}$ 
The joint national committee reports on hypertension have provided clearer details on the concept of hypertension to the scientific community ${ }^{(5)(8)}$

Actual blood pressure increases with age and exhibits a wide range of changes within the same individual in a 24 hour period. It can invariably increase in response to physical stress, temperature, season, food intake sleep or sexual activity ${ }^{(6)}$

Risk factors for hypertension includes increasing age, black race, heredity, sedimentary lifestyle, obesity, physical and emotional stress, high fat diet, high salt intake, excessive consumption of stimulants e.g. caffeine containing beverages, smoking and certain endocrinopathies. ${ }^{(7),(9),(10)}$

The Framingham study has made an important contribution to the ancient history of high blood pressure. It has shown that hypertension can cause heart failure, kidney damage cerebral haemorrhage and redinopathy ${ }^{(3)}$ mortalities.

As a result, long-term hypertensive treatment is needed to reduce these associated morbidities and

\section{Materials And Methods}

\section{Study Location}

The study was conducted at the department of pharmacology, Madonna University Elele, Port-Harcourt South, South Nigeria.

\section{Material/Preparation}

The leaves of Newbouldia Laevis were collected from Umunze, one of the researchers home town in Orumba-South L.G.A of Anambra State. The plant was then identified by the department of pharmacology faculty of pharmaceutical sciences, Madonna University. The leaves were air dried and ground into powder using a grinding machine. The powdered plant measured 250 gram.

\section{Equipment Used Include}

Operating table, cannula, operating scissors, Needles and syringe, thread, blood pressure transducer, Graph, weighing scale, measuring cylinder marker, Rotor evaporator, round bottom flask, small ampoule bottle, Petri dish, spatula.

Extract: The leaves of the plant were air dried at room temperature and reduced to coarse powder using an electric blender. $250 \mathrm{~g}$ of powdered plant was extracted with 2litres of methanol in a cold maceration process for 48hours, where it was allowed to settle and the supernatant filtered with a clean white handkerchief and then with No. 1 Whatman filter paper and the supernatant removed was $244 \mathrm{mls}$. The deposit was later decanted. The crude methanol extract was concentrated using a rotor evaporator which was kept at a temperature of $40^{\circ} \mathrm{C}$. The extract weighed 36.5 gram.

\section{Experimental Procedure:}

Ten adult cats of either sex with weight ranging from $1.8-2.5 \mathrm{~kg}$ were obtained from the animal house of the Department of Pharmacology and Toxicology, University of Nigeria, Nsukka were used for the study. They were housed in wired cages arranged in rows and kept in the animal house of the Department of pharmacology and Toxicology Madonna University Elele. The animals had free access to food and water and were maintained under standard conditions while in the animal house.

\section{Method of Cannulated Cat Experiment}

The operating table was set up and ten adult cats of weights ranging from $1.8-2.5 \mathrm{~kg}$ were given pentobarbitone injection $(40 \mathrm{mg} / \mathrm{kg}$ ) intraperitoneally. A little quantity of diethylether was given by inhalation so as to fully anaesthesize the animals. The animals were laid supine with the four limbs tied firmly to the table.

Incisions were made on the neck region and the left hind limbs and cannulas were fixed on three points:

(a) The Femoral Vein:- This was carefully isolated using a dissecting forceps; a thread was tied on the vein to prevent flow of blood while fixing the cannula after which it was untied. The other end of the cannula was then connected to a needle and syringe for the administration of drugs.

(b) The Carotid Artery: Using the same procedure, a cannula was also inserted in the left carotid artery and the other end connected to a blood pressure transducer which was also linked to an electrical recorder which made traces showing the effect of the drug on the blood pressure of the animal. 
(c) The Trachea: This was cut open a little and a fitting cannula was fixed to it, a thread was then tied around the area to prevent the cannula from pulling out. This was to prevent the animal from breathing through the nostril which might agitate the animal and facilitate consciousness.

Heparin was injected through the femoral vein to aid free flow of blood and to avoid clotting of blood and blockage of blood vessels during the experiment. The different doses of the extract were administered through the femoral vein until the end of the experiment. This procedure was carried out on each of the animals. The animals were grouped into two groups of five in each group, and the average results analyzed.

\section{Statistical Analysis}

Data was expressed as mean \pm Standard error of mean (S.E.M) Statistical comparisons were performed by one way ANOVA followed by Turkey-Kramer Multiple comparison Test, and student-Keuls multiple comparison. Test and the value were considered statistically significant when P. value is less than 0.05 i.e. P $<0.05$. Statistical comparisons, calculations and graphs were done using Graph Pad Instant version 3.0 and Microsoft Excel 2007.

\section{Acute Toxicity Test (LD 50)}

This test was to determine the safety of the Newbouldia Laevis extract when taken orally. It was carried out in mice using the Lorke's method (Lorke 1983). Days prior to the test, the mice were fasted for $24 \mathrm{hrs}$ but had free access to water. The animals (13 in number) were grouped into two stages. The first stage contained three mice in three groups and the second stage contained one mice in four groups. Doses of 10, 100 and $1000 \mathrm{mg} / \mathrm{kg}$ of the extract was orally administered for the first stage and no death was recorded after 24hours. Then, doses of $1500,2500,3500$ and $5000 \mathrm{mg} / \mathrm{kg}$ were administered for the second stage and also no death was recorded after $24 \mathrm{hrs}$. The result showed that the extract is safe and well tolerated for oral route at a loading dose of $50-5000 \mathrm{mg} / \mathrm{kg}$ body weight.

Percentage yield of Extract:

\section{Results}

$\begin{aligned} P & =\frac{\text { weight of Extract } \times 100}{\text { Weight of Powdered material }} \\ & =\frac{36.5}{250} \times 100=14.6 \%\end{aligned}$

\section{TABLES AND FIGURES}

Table 1: Effect of the Extract and drugs on the blood pressure of Cats: Group 1

\begin{tabular}{|l|c|l|l|}
\hline Drug & $\begin{array}{l}\text { Concentrati } \\
\text { on (ug) }\end{array}$ & $\begin{array}{l}\text { Peak of } \\
\text { Effect } \\
\text { (length)m } \\
\text { m }\end{array}$ & $\begin{array}{l}\text { Duration } \\
\text { width } \\
(\mathbf{m m})\end{array}$ \\
\hline 1. Adrenaline & 10 & 2.65 & 5.6 \\
\hline 2. Acetylcholine & 20 & 3.45 & 2.45 \\
\hline 3. Extract & 10 & -2.8 & 0.3 \\
\hline 4. Extract & 20 & -3.0 & 0.25 \\
\hline 5. Extract & 40 & -3.5 & 0.38 \\
\hline 6. Extract & 80 & -3.9 & 0.7 \\
\hline 7. Extract & 100 & -4.1 & 0.65 \\
\hline 8. Control & 500 & & \\
\hline
\end{tabular}

Table 2:

Group 2

\begin{tabular}{|l|l|c|c|c|}
\hline S/N0 & \multicolumn{1}{|c|}{ Drug } & $\begin{array}{c}\text { Concentrati } \\
\text { on (ug) }\end{array}$ & $\begin{array}{c}\text { Peak of } \\
\text { Effect } \\
\text { (length } \\
\text { mm) }\end{array}$ & $\begin{array}{c}\text { Duration } \\
\text { (width } \\
\text { mm) }\end{array}$ \\
\hline 1. & Acetylcholine & 20 & -4.75 & 1.38 \\
\hline 2. & Adrenaline & 10 & 2.0 & 6.4 \\
\hline 3. & Extract & 10 & -3.3 & 0.5 \\
\hline 4. & Extract & 20 & -3.5 & 0.4 \\
\hline 5. & Extract & 40 & -3.75 & 0.45 \\
\hline 6. & Extract & 80 & -3.85 & 0.5 \\
\hline 7. & Extract & 100 & -4.1 & 0.6 \\
\hline 8. & Control & 100 & & \\
\hline
\end{tabular}


Table 3: Average effect of the two groups.

\begin{tabular}{|l|l|c|c|c|}
\hline $\begin{array}{l}\text { S/N } \\
\text { O }\end{array}$ & Drug & $\begin{array}{l}\text { Concentrat } \\
\text { ion }(\mathbf{u g}\end{array}$ & $\begin{array}{l}\text { Peak of } \\
\text { Effect } \\
\text { (length } \\
\text { mm) }\end{array}$ & $\begin{array}{l}\text { Duration } \\
\text { (width mm) }\end{array}$ \\
\hline 1. & Acetylcholine & 20 & -4.1 & 1.92 \\
\hline 2. & Adrenaline & 10 & 2.33 & 6.0 \\
\hline 3. & Extract & 10 & -3.05 & 0.4 \\
\hline 4. & Extract & 20 & -3.25 & 0.33 \\
\hline 5. & Extract & 40 & -3.63 & 0.42 \\
\hline 6. & Extract & 80 & -4.0 & 0.6 \\
\hline 7. & Extract & 100 & -4.1 & 0.63 \\
\hline 8. & Control & 500 & & \\
\hline
\end{tabular}

Table 4: Average Result of Effect Of The Extract And Drugs On The Blood Pressure Of Cats Mean \pm SEM

\begin{tabular}{|l|l|c|l|}
\hline $\begin{array}{l}\text { S/N } \\
\text { o }\end{array}$ & $\begin{array}{l}\text { Drug/ } \\
\text { Extract }\end{array}$ & $\begin{array}{l}\text { Concentration } \\
\text { (ug) }\end{array}$ & $\begin{array}{l}\text { Peak of Effect } \\
\text { (length mm) }\end{array}$ \\
\hline 1. & Acetylcholine & 20 & $-4.1 \pm 7.07$ \\
\hline 2. & Adrenalin & 10 & $2.33 \pm 5.20$ \\
\hline 3. & Extract & 10 & $-3.05 \pm 0.44$ \\
\hline 4. & Extract & 20 & $-3.25 \pm 0.2$ \\
\hline 5. & Extract & 40 & -3.63 \\
\hline 6. & Extract & 80 & $-4.0 \pm 4.25$ \\
\hline 7. & Extract 1 & 100 & $-4.1 \pm 5.02$ \\
\hline
\end{tabular}

The values were considered statistically significant when $\mathrm{P}$ value is less than 0.05 i.e. $\mathrm{P}<0.05$

Figure 1: Bar chart comparing concentration of the drug/extract with the peak of effect.

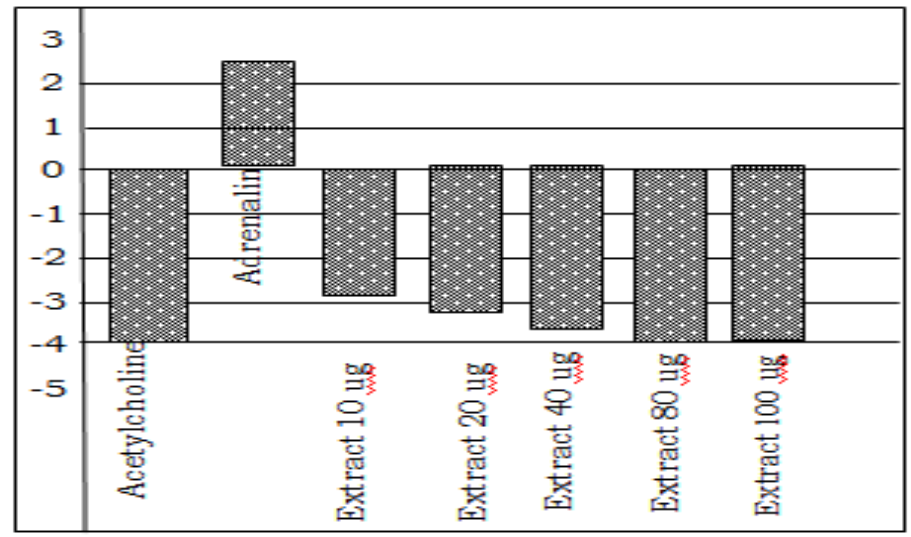

Figure 2: Bar Chart comparing concentration of the drug/Extract with the duration of effect.

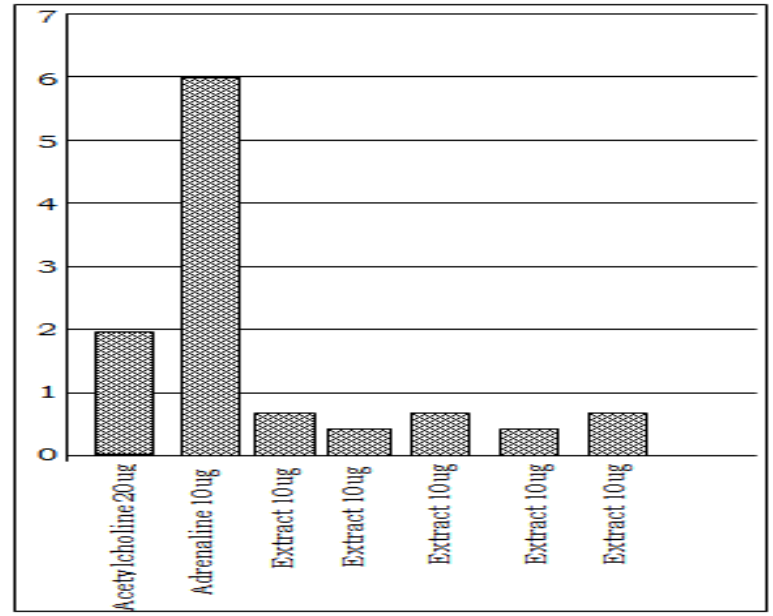




\section{LD 50 Observation}

At the dose of $500 \mathrm{mg} / \mathrm{kg}$ which is the highest dose, no death was observed, which showed that the extract was not toxic.

Table 5: Result of Acute Toxicity Test (LD50)

\begin{tabular}{|l|l|}
\hline $\begin{array}{l}\text { First stage } \\
\text { Dose of extract } \mathbf{( m g} / \mathbf{k g})\end{array}$ & $\begin{array}{l}\text { First stage } \\
\text { Mortality }\end{array}$ \\
\hline 10 & $0 / 3$ \\
\hline 100 & $0 / 3$ \\
\hline 1000 & $0 / 3$ \\
\hline Second stage & Second stage \\
Dose of extract $(\mathrm{mg} / \mathrm{kg})$ & $\begin{array}{l}\text { First stage } \\
\text { Mortality }\end{array}$ \\
\hline 1500 & $0 / 1$ \\
\hline 2500 & $0 / 1$ \\
\hline 3500 & $0 / 1$ \\
\hline 5000 & $0 / 1$ \\
\hline
\end{tabular}

\section{Discussion}

Hypertension is a quantitative condition which may be primary (essential) or secondary to other medical conditions ${ }^{(8) .}$ Essential hypertension is a constitutional condition where heredity is of major importance. It arises from the interaction of inherent biological traits, behaviour and environmental factors in a genetically susceptible individual $^{(7)}$

Hypertension is an important cause of morbidity and mortality in developing countries. Therefore the aim of this research is to determine the antihypertensive property of Newbouldia laevis.

The test performed was designed to screen the antihypertensive activity of the crude extract employing ten adult cats of either sex, which were cannulated at three points. The study and observations revealed that the methanol extract of Newbouldia laevis leaf exhibited an antihypertensive action ${ }^{(1)}$

Phytochemical screening on Newbouldia laevis conducted by Gofner S; et. al. showed the presence carbohydrates, reducing sugars, alkaloids, tannins, flavonoids, resin, proteins, oil, and acid compounds. ${ }^{(2)}$

These classes of compounds are known to show curative activity against several diseases and therefore could explain its use traditionally for the treatment of a wide range of ailments ${ }^{(2)(3)}$

In a similar work also by Akunyili D.N, the ethanoliic extract of Newbouldia laevis leaves showed some anti convulsant properties ${ }^{(3)}$

\section{Conclusion And Recommendation}

The test performed was designed to screen the anti-hypersensitive activity of the crude extract of Newbouldia laevis by employing ten adult cats of either sex, which were cannulated at three points.

The investigation revealed that the methanol extract of Newbouldia laevis contains pharmacologically active ingredients with anti hypertensive properties.

Further studies should focus on how to fractionate and purify the extract for use in the treatment of hypertension in man.

\section{References}

[1]. Arbonnier M. Trees and Shrubs of West Africa Dry Zones. $5^{\text {th }}$ Edition 2004 page 194

[2]. Gofner S., Wolfender J.L, Nianya M, Hostesttmann K. Phenylpropanoid Glycosides from Newbouldia laevis Rools. Pyetochemistry 1997; 44 (4) 687-690.

[3]. Akunyili D.N. Anticonvulsant activity of the Ethanolic Extract of Newbouldia laevis. $2^{\text {nd }}$ NAAP conference 2000 , page $155-158$ Kannel W.B

[4]. Blood pressure as a cardio vascular risk factor: Prevention and Treatment. 1996; 275, 1571-1576.

[5]. Bost L. Primatesta P; Dong W. Blood pressure Evidence from Health survey for England 1999; 13 (2): $123-128$

[6]. Swarles J.D. Essential Hypertension. Oxford Medical Publications $3^{\text {rd }}$ Edition 1992; 2527-2543.

[7]. Oparil S. Arterial Hypertension Cecil Textbook of Medicine 19 $9^{\text {th }}$ Edition 1992: 253-269.

[8]. Mulatero P: Bertello C. Verhovez A. Current Hypertension Reports 2009; U (3): 217-223.

[9]. Parati G; Stergiou G.S; Asmer R. European Society of Hypertension. Guildlines for Blood pressure monitoring at home 2008; 26 (8) $1505-1526$

[10]. Nelson Mark. Drug Treatment of Elevated Blood pressure 2010, (11) 33: 